\title{
Potential of bioapatite hydroxyls for research on archeological burned bone
}

\author{
Adriana P. Mamede, Ana R. Vassalo, Giampaolo Piga,
} Eugénia Cunha, Stewart F. Parker, M. Paula M. Marques, Luís A. E. Batista de Carvalho and David Gonçalves

\section{Published version information}

Citation: AP Mamede et al. "Potential of bioapatite hydroxyls for research on archeological burned bone." Analytical Chemistry, vol. 90, no. 19 (2018): 1155611563.

\section{DOI: $10.1021 /$ acs.analchem. 8 b02868}

This version is made available in accordance with publisher policies. Please cite only the published version using the reference above. This is the citation assigned by the publisher at the time of issuing the AAM. Please check the publisher's website for any updates. 


\title{
The potential of bioapatite hydroxyls for research on archaeological burned bone
}

\author{
Adriana P. Mamede ${ }^{1}$, Ana R. Vassalo ${ }^{1,2,3}$, Giampaolo Piga ${ }^{3}$, Eugénia Cunha ${ }^{3,4}$, Stewart F. Parker ${ }^{5}$,
} M. Paula M. Marques ${ }^{1,4}$, Luís A. E. Batista de Carvalho ${ }^{1 *}$, David Gonçalves ${ }^{2,3,6}$

\footnotetext{
${ }^{1}$ Unidade de I\&D “Química-Física Molecular”, Department of Chemistry, University of Coimbra, Portugal

${ }^{2}$ Research Centre for Anthropology and Health (CIAS), Department of Life Sciences, University of Coimbra, Portugal

${ }^{3}$ Laboratory of Forensic Anthropology, Centre for Functional Ecology, Department of Life Sciences, University of Coimbra, Portugal

${ }^{4}$ Department of Life Sciences, University of Coimbra, Portugal

${ }^{5}$ ISIS Facility, STFC Rutherford Appleton Laboratory, Chilton, Didcot, OX 11 0QX, United Kingdom

${ }^{6}$ Archaeosciences Laboratory, Directorate General for Cultural Heritage (LARC/CIBIO/InBIO), Lisbon, Portugal
}

*Corresponding author:

Luís A. E. Batista de Carvalho

Unidade de I\&D "Química-Física Molecular”, Department of Chemistry, University of Coimbra, 3004-535 Coimbra, Portugal

labc@ci.uc.pt

Phone: +351 239826541 


\begin{abstract}
The estimation of the maximum temperature affecting skeletal remains was previously attempted via infrared techniques. However, fossilization may cause changes in the composition of bones that replicate those from burned bones. We presently investigated the potential of three $\mathrm{OH} / \mathrm{P}$ indices (intensity ratios of characteristic infrared bands for $\mathrm{OH}$ and phosphate groups, respectively) to identify bones burned at high temperatures $\left(>800{ }^{\circ} \mathrm{C}\right)$ and to discriminate between fossil and burned archaeological bones, using vibrational spectroscopy: combined Inelastic Neutron Scattering (INS) and FTIR-ATR.

The INS analyses were performed on two unburned samples and 14 burned samples of human femur and humerus. FTIR-ATR focused on three different samples: i) modern bones comprising 638 unburned and 623 experimentally burned (400-1000 $\left.{ }^{\circ} \mathrm{C}\right)$ samples; ii) archaeological cremated human skeletal remains from the Bronze and Iron Ages comprising 25 samples; and iii) fossil remains of the Reptilia class from the Middle Triassic to the Eocene. The OH/P indices investigated were $630 \mathrm{~cm}^{-}$ $1 / 603 \mathrm{~cm}^{-1}, 3572 \mathrm{~cm}^{-1} / 603 \mathrm{~cm}^{-1}$, and $3572 \mathrm{~cm}^{-1} / 1035 \mathrm{~cm}^{-1}$.

The $\mathrm{OH}$ signals became visible in the spectra of recent and archaeological bones burned between 600 and $700{ }^{\circ} \mathrm{C}$. Although they have episodically been reported in previous works, no such peaks were observed in our fossil samples thus suggesting that this may be a somewhat rare event. While high crystallinity index values should always correspond to clearly visible hydroxyl signals in burned bone samples, this is not always the case in fossils which may be used as a criterion to exclude burning as the agent responsible for high crystallinity ratios.
\end{abstract}

\title{
Keywords
}

Bioarchaeology; Chemical Anthropology; Hydroxyl Groups; Infrared Spectroscopy; Inelastic Neutron Scattering; Burned Bones; Cremation

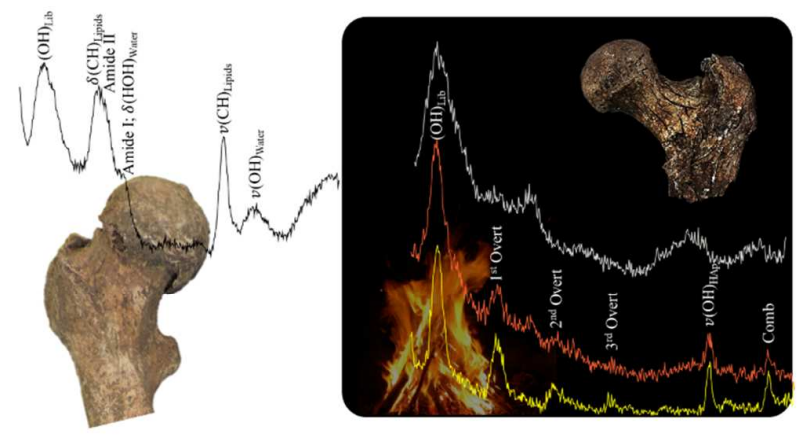


The potential of vibrational spectroscopy for the analysis of skeletal remains has been demonstrated since the 1990's (1-16). For some time now, biological anthropologists have been attempting to estimate the maximum temperature at which a burned human body was exposed to by examining its skeletal remains (e.g. 7,17-20). The ability to precisely determine this parameter would improve our inferences regarding human skeletal remains in both archaeological and forensic settings. Heat may cause numerous changes in bones and teeth, depending on the temperature, that interfere with the reliability of bioanthropological analyses (e.g. 21-30). Therefore, knowing the burning temperature would be extremely useful to biological anthropologists, in order to assess how the burned bones have been altered. Bioarchaeologists often attempt to assess cooking practices and fuel management, for example regarding the level of investment on a given cremation, namely how intense it was and how much combustible material it required (e.g. 31-33). Despite all efforts, our understanding of the chemical phenomena undergone by bone tissue when subject to heat is still incomplete. As a result, methods for temperature estimation lack precision, although clear improvements have been made in recent years $(7,10,34-37)$.

Human bone tissue is composed of an organic matrix (25\%, mostly type I collagen), water (10\%) and an inorganic component (65\%) (38-40). The latter is known as bioapatite, a non-stoichiometric form of hydroxyapatite $(12,41)$, of chemical formula $\mathrm{Ca}_{10}\left(\mathrm{PO}_{4}\right)_{6-\mathrm{x}}(\mathrm{OH})_{2-\mathrm{y}}\left(\mathrm{CO}_{3}{ }^{2-}\right)_{\mathrm{x}+\mathrm{y}}$. In vivo, carbonates may substitute phosphate (type B substitution) and/or hydroxyl (type A substitution) groups (42-44). After death, diagenetic alterations lead to the loss of carbonates (mainly type B) and of ion uptake (such as fluoride from the surroundings) as a consequence of collagen hydrolysis $(2,45,46)$. Similar alterations were detected in bones exposed to heat $(16,47-49)$.

Although type A carbonate substitution is much less common than type B (43), the $\mathrm{OH}$ content in bone has been controversial for many years. Some authors state that the bioapatite lattice contains little or no hydroxyl groups $(43,50,51)$, while others have detected hydroxyls in defatted and deproteinated bone $(52,53)$ and in intact bone $(54)$. However, incrementally heated bone tissue clearly showed the 
$\mathrm{OH}^{-}$moieties $(16,47)$, reaching the purest form of hydroxyapatite at very high temperatures (55) thus representing a possible target for burning temperature estimation in human bones.

Vibrational spectroscopy, in particular Fourier transform infrared (FTIR) spectroscopy, has taken a major role in the study of heat-induced changes of burned bones allowing the identification of major chemical and structural alterations, contaminants, and new inorganic phases $(7,11,12,16,55$, 59). Based on these, several spectral relationships were developed to attempt to quantify these heatinduced variations $(7,8,12,16,37,60-62)$. However, to observe the complete vibrational profile of bone samples, infrared spectroscopy must be combined with complementary vibrational techniques: Raman and inelastic neutron scattering (INS) spectroscopies. Although Raman spectroscopy provides important information about bone composition (57,63-66), its application to bones burned at low and medium temperatures $\left(<700{ }^{\circ} \mathrm{C}\right)$ is hindered by the high intrinsic fluorescence of these samples $(67)$. INS, on the other hand, has proven extremely useful for confirming the presence of hydroxyls in heated bones as well as to unveil crystallinity changes within the bioapatite network $(52,53,55)$. The major advantage of the INS technique lies in the fact that the intensity of the signals is proportional to the number of hydrogen atoms, enabling straightforward quantification of the hydroxyl content.

In their attempt to better describe heat-induced compositional and structural changes in bone, Snoeck et al. (16) were the first to propose the OH/P ratio, obtained through FTIR-ATR, as a valuable index for this analysis. They calculated the ratio between the intensity of the $\mathrm{OH}$ libration from hydroxyapatite $\left(\mathrm{OH}_{\text {lib }}\right)$ band, at $630 \mathrm{~cm}^{-1}$, and the $v_{4}\left(\mathrm{PO}_{4}{ }^{3-}\right)$, at $603 \mathrm{~cm}^{-1}$ (Equation 1), which represents the amount of $\mathrm{OH}$ groups within bioapatite:

$$
b / a=O H_{l i b} / v_{4}\left(P_{4}\right)=630 \mathrm{~cm}^{-1} / 603 \mathrm{~cm}^{-1}
$$

However, other alternatives are available for the calculation of the $\mathrm{OH} / \mathrm{P}$ relationship. Taylor et al. (52) reported the emergence of the $\mathrm{OH}$ stretching mode $(v(\mathrm{OH}))$, at $c a .3570 \mathrm{~cm}^{-1}$, concomitantly with the $\mathrm{OH}_{\text {lib }}$ signal in FTIR spectra. So, as recently suggested by Mamede et al. (44), both FTIR signals $\left(\mathrm{OH}_{\text {lib }}\right.$ and $\left.v(\mathrm{OH})\right)$ may be used to estimate the hydroxyl content in bone by calculating the 
$v(\mathrm{OH})$ band intensity, at $3572 \mathrm{~cm}^{-1}$ in relation to either the $v_{4}\left(\mathrm{PO}_{4}{ }^{3-}\right)$, at $603 \mathrm{~cm}^{-1}$ (Equation 2), or the $v_{3}\left(\mathrm{PO}_{4}{ }^{3-}\right)$, at $1035 \mathrm{~cm}^{-1}$ (Equation 3), as schematically represented in Figure 1.

$$
\begin{aligned}
& d / a=v(\mathrm{OH}) / v_{4}\left(\mathrm{PO}_{4}\right)=3572 \mathrm{~cm}^{-1} / 603 \mathrm{~cm}^{-1} \\
& d / c=v(\mathrm{OH}) / v_{3}\left(\mathrm{PO}_{4}\right)=3572 \mathrm{~cm}^{-1} / 1035 \mathrm{~cm}^{-1}
\end{aligned}
$$

Given the multiple possible ways of calculating the $\mathrm{OH} / \mathrm{P}$ ratio, the objective of the present study was to explore which of the three previously suggested indices is more useful and reliable for the analysis of burned human skeletal remains, particularly those recovered from archaeological contexts. Therefore, the three mathematical ratios (Equations 1, 2 and 3) were applied and compared to the INS results in order to understand which of them better describe the heat-induced alterations in bioapatite. Additionally, the potential of the $\mathrm{OH}$ vibrational bands to differentiate recent and archaeological burned bones from very ancient fossil bones, i.e. in which the organic component has been entirely replaced by mineral substances, was investigated. This distinction is important because the crystallinity index is altered in both, so its discrimination ability to identify burned bones may often be jeopardized. The presence or absence of $\mathrm{OH}$ vibrational bands may therefore act as an additional criterion for discrimination.

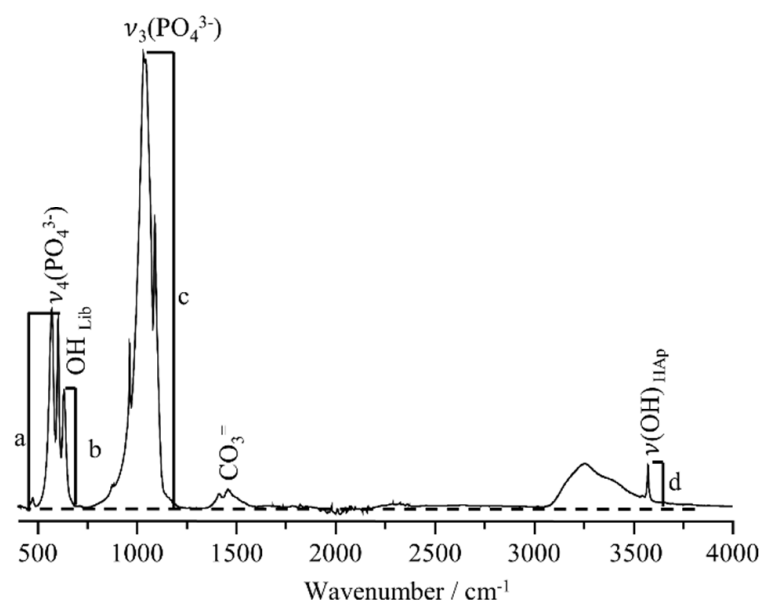

Figure 1. FTIR-ATR spectra of human femur burned at $1000{ }^{\circ} \mathrm{C}$ and representation of the different $\mathrm{OH} / \mathrm{P}$ relationships based on the intensity of distinct spectral bands. $\mathbf{a}, \mathbf{b}, \mathbf{c}$ and $\mathbf{d}$ represent the intensity of the $v_{4}\left(\mathrm{PO}_{4}\right)\left(603 \mathrm{~cm}^{-1}\right), \mathrm{OH}_{\mathrm{lib}}\left(630 \mathrm{~cm}^{-1}\right)$, $v_{3}\left(\mathrm{PO}_{4}\right)\left(1035 \mathrm{~cm}^{-1}\right)$ and $v(\mathrm{OH})\left(3572 \mathrm{~cm}^{-1}\right)$, respectively. 


\section{EXPERIMENTAL}

\section{Samples}

For the INS analysis, femoral and humeral diaphyses of one skeleton (CC_NI_42) were used. This skeleton came from the cemetery of Capuchos (Santarém, Portugal) and has been donated to the University of Coimbra, thus having the same provenance of those from the $21^{\text {st }}$ Century Identified Skeletal Collection of the Laboratory of Forensic Anthropology (68). The total sample comprised 14 bone sections. Diaphyses were sectioned and 7 sections of each bone were burned separately. The femur and humerus samples were burned under controlled conditions in an electric oven (model Barracha K-3 three-phased 14A): 400, 500, 600, 700, 800, 900 and $1000{ }^{\circ} \mathrm{C}$, for 120 minutes, at a heating rate of $6-10^{\circ} \mathrm{C} / \mathrm{min}$.

Four other unclaimed skeletons of unknown sex and age at death were used in the FTIR-ATR measurements (CC_NI_31, CC_NI_32, CC_NI_33, and CC_NI_34). Bone powder samples were collected from long bones (seven sampling loci), short bones (three sampling loci), and irregular bones (two sampling loci) from both left and right sides of each skeleton. In total, 168 bones (638 unburned samples) were used, including 47 long bones (329 samples), 72 short bones (213 samples) and 48 irregular bones (96 samples). This terminology is based on the one used by Bass (Bass, 1995). Therefore, long bones refer to humeri, radii, ulnae, femora, tibiae and fibulae. Short bones refer to bones from the metacarpus and metatarsus. For simplification, clavicles were analysed as short bones because only three sample loci were used. Finally, irregular bones referred to calcanei, tali, cuboids, naviculars and cuneiforms.

For experimentally burned bones, a total of 623 bone powder samples were used. This means that 15 potential post-burning samples ( 8 from long bones, 4 from short bones, and 3 from irregular bones) were unavailable for FTIR-ATR analysis. The reason for this was that the right femur of individual 34 was not burned because it had a prosthesis. For the remaining cases, samples were not taken due to poor bone preservation aggravated by the sampling procedure and the heat treatment. 
The experimental burning was done on the same equipment mentioned above and following the same maximum temperature thresholds and burning durations. The distribution of samples by maximum temperature is given in Table S-1 of the supporting information. Overall, this study investigated 1261 bone powder samples. For comparison purposes a highly crystalline calcium hydroxyapatite sample $\left(\mathrm{Ca}_{10}\left(\mathrm{PO}_{4}\right)_{6}(\mathrm{OH})_{2}, \mathrm{Ca} / \mathrm{P}=1.67\right)$ SRM $2910 \mathrm{~b}$ from NIST, Gaithersburg/MA (USA) was used.

A third set of bones comprising 25 samples from various archaeological sites in Italy and Spain was used for comparison with the experimentally burned modern bones, aiming to assess the suitability of the three $\mathrm{OH} / \mathrm{P}$ indices for an accurate analysis of this kind of material (Table S-2). Those samples were collected from cremated human remains (bones and teeth) recovered from four different necropoleis: Iron Age necropolis of Sebes (Tarragona, Spain: n=3); Iron Age necropolis of Monte Sirai (Carbonia, Italy: $\mathrm{n}=12$ ); Bronze Age necropolis of Can Missert (Terrassa, Spain: $\mathrm{n}=$ 5); and Iron Age necropolis of Aguilar de Montuenga (Soria, Spain: $\mathrm{n}=5$ ).

Finally, a fourth set comprised 25 samples (bones and teeth) from 8 chronologically diverse paleontological sites, and were also used not only for comparison purposes but to assess how frequently $\mathrm{OH}$ peaks occur in this kind of material (Table S-3), which has been reported to be quite rare $(69,70)$. The samples spanned from the Middle Triassic epoch (Anisian age) to the Eocene epoch (Priabonian age) and belong to varied types of specimens from the reptilia class. Figure 2 show photo assemblies of archaeological and fossil samples used in this study. INS

The INS experiments were performed at the ISIS Neutron and Muon Source of the Rutherford Appleton Laboratory (71), using the direct geometry time-of-flight, broad range spectrometer MAPS (72). Three incident energies were used - 5240, 2024 and $968 \mathrm{~cm}^{-1}$ - to accurately observe the bands from the $\mathrm{OH}$ libration, its overtones and stretching modes of hydroxyapatite.

The samples were wrapped in aluminium foil and fixed onto thin walled aluminium cans. To reduce the impact of the Debye-Waller factor on the observed spectral intensity, the samples were 
cooled to $c a$. $10 \mathrm{~K}$. Data were recorded in the energy range of 0 to $6000 \mathrm{~cm}^{-1}$ and reduced into energy transfer spectra using the MANTID program (version 3.4.0) (73).

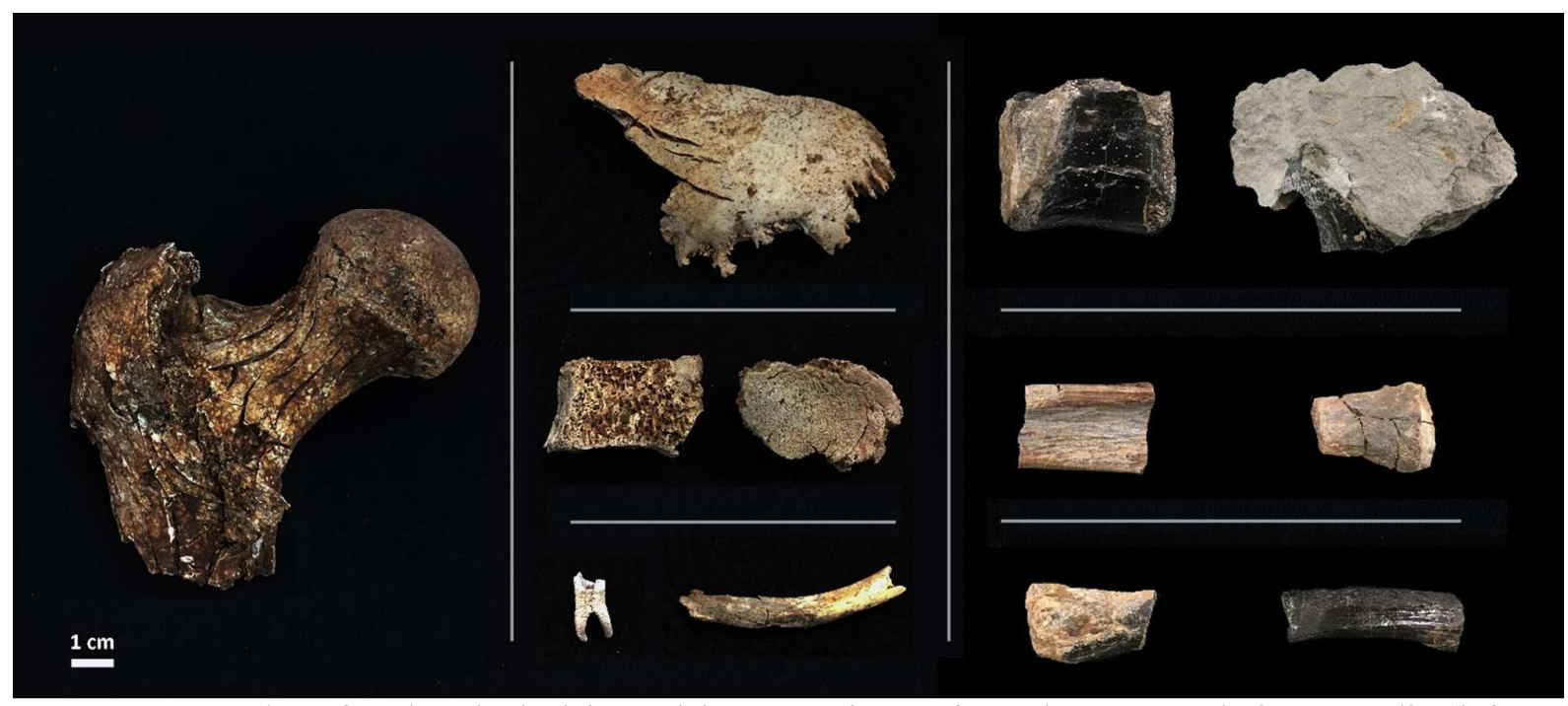

Figure 2. Examples of archaeological burned bone specimens from the Monte Sirai necropolis (left and central columns) and fossil materials (right column) used in this study. Left column: T252 femur. Central column: T250 skull (top); T252 vertebra (middle); T250 tooth (bottom left); T252 rib (bottom right). Right colum: MCD-5589 sacral vertebra from Isona (Lleida, Spain) (top left); MD-6645 rib from Isona (Lleida, Spain) (middle left). Right column: MB 6-5 20101 from Isona (Lleida, Spain) (top right); NE12F ischion from Vilamitjana (Lleida, Spain) (middle right). Both bottom fragments represent the MCD-6647 rib from Isona (Lleida, Spain).

\section{FTIR-ATR}

FTIR spectra of fossil and archaeological cremated bones were collected in ATR mode using a Bruker Alpha spectrometer with a Bruker Platinum-ATR accessory, as absorbance vs wavenumber spectra in the range $370-4000 \mathrm{~cm}^{-1}$, with a resolution of $4 \mathrm{~cm}^{-1}$. Each spectrum was obtained by averaging 256 interferograms. The loose powder was dispersed inside a cavity of spheroidal shape with its surface aligned to the plate defining it.

For the analysis of recent modern human bone a Bruker Optics Vertex 70 FTIR spectrometer, purged by $\mathrm{CO}_{2}$-free dry air with a Platinum ATR single reflection accessory was used. A Ge on $\mathrm{KBr}$ substrate beamsplitter and a liquid nitrogen cooled wide band mercury cadmium telluride (MCT) detector were used to record the spectra of pure bone powder, in the spectral range $400-4000 \mathrm{~cm}^{-1}$, 128 scans, at $2 \mathrm{~cm}^{-1}$ resolution. A 3-term Blackman-Harris apodization function was applied. The 
spectra were corrected for the wavelength dependence of the penetration depth of the electric field in ATR (considering the mean reflection index of sample 1.25), using the standard Opus software option (version 7.5). Under these conditions, the wavenumber accuracy is better than $1 \mathrm{~cm}^{-1}$.

\section{Statistical Analysis}

Potential statistical differences among bone types were tested by using a Kruskall-Wallis test to determine if the data could be pooled into the same analysis. This was done for the three $\mathrm{OH} / \mathrm{P}$ indices. In order to acknowledge if the information provided by them is similar, multicollinearity was assessed and Spearman rho's rank correlation tests were implemented. This issue was further investigated by assessing multicollinearity among the three indices. All statistical analyses were performed using the IBM SPSS Statistics software (version 23.0).

\section{RESULTS AND DISCUSSION}

INS

Using an incident energy of $5240 \mathrm{~cm}^{-1}$, with the broad range MAPS spectrometer it is possible to assess both $\mathrm{OH}_{\text {lib }}$ and $v(\mathrm{OH})$ signals simultaneously, as depicted in Figure 3. While the $\mathrm{OH}_{\mathrm{lib}}$ band was present in all samples, the $v(\mathrm{OH})$ stretch mode started being visible only at $600^{\circ} \mathrm{C}$. Above this temperature, the $1^{\text {st }}$ overtone of the $\mathrm{OH}_{\text {lib }}$ and a band arising from the combination of the $\mathrm{OH}$ libration and stretching modes (comb) became observable. In turn, the $2^{\text {nd }}$ and $3^{\text {rd }}$ overtones of the librational mode were visible in the spectra from samples burned at 800 and $1000{ }^{\circ} \mathrm{C}$, respectively (Figure 3). This corroborates the results obtained by Marques et al. (2016).

As expected, all bands became progressively sharper as the temperature increased, thus confirming an increased lattice organisation. Concerning the hydroxyl content in bioapatite, the intensity of the corresponding bands increased from 700 to $900{ }^{\circ} \mathrm{C}$ (in agreement with previous results (55) remaining constant at temperatures above $900^{\circ} \mathrm{C}$.

These results allowed us to accurately analyse the FTIR-ATR data in order to correctly apply the different $\mathrm{OH} / \mathrm{P}$ ratios under study. 


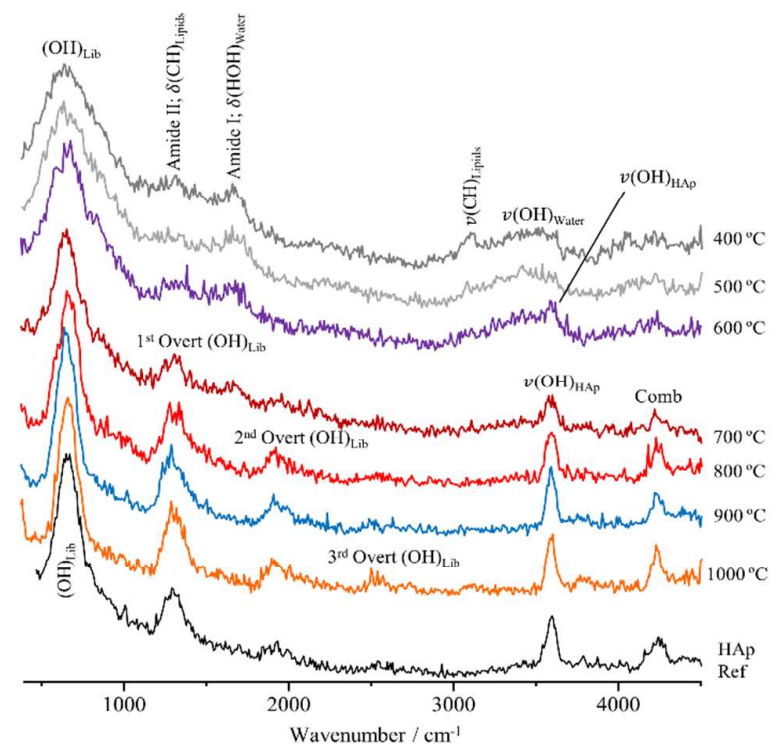

Figure 3. INS spectra recorded on MAPS (with $5240 \mathrm{~cm}^{-1}$ incident energy) for human femur (skeleton CC_NI_42), burned from 400 to $1000{ }^{\circ} \mathrm{C}$ and hydroxyapatite reference spectrum. The INS spectrum of reference calcium hydroxyapatite is also shown.

FTIR-ATR

Previous FTIR studies on human bone reported that all the organic material is lost by $500{ }^{\circ} \mathrm{C}$ $(40,74)$. In our experiments, the signals referring to the organic component, in particular amide I and II typical bands from proteins, disappeared only at temperatures higher than $700{ }^{\circ} \mathrm{C}$ (Figure 4). Above this temperature, only hydroxyapatite was detected. This observation is in agreement with previous FTIR experiments $(37,41,61)$. The differences among reported experiments on burned bones may be related to the diversified durations of burning. For example, Wang et al. (40) burned their porcine samples for four hours while Etok et al. (74) experimentally heated their mammal samples for 6 hours. In contrast, in the present work the bone samples were burned for 2 hours. Other authors, who obtained results similar to ours, also burned their samples for shorter times, below or equal to 45 minutes $(37,61)$. Different burning periods result in distinct spectral profiles for the same temperature range. In this study, the smaller time span we used was not enough to completely discard the organic phase from our samples at temperatures below $700{ }^{\circ} \mathrm{C}$. Nevertheless, shorter burning duration is closer to real events. It should be emphasized, as argued before $(35,36,61)$, that the 
burning duration is an influential variable that might interfere with attempts of estimating the heating temperature to which a certain sample was subjected.

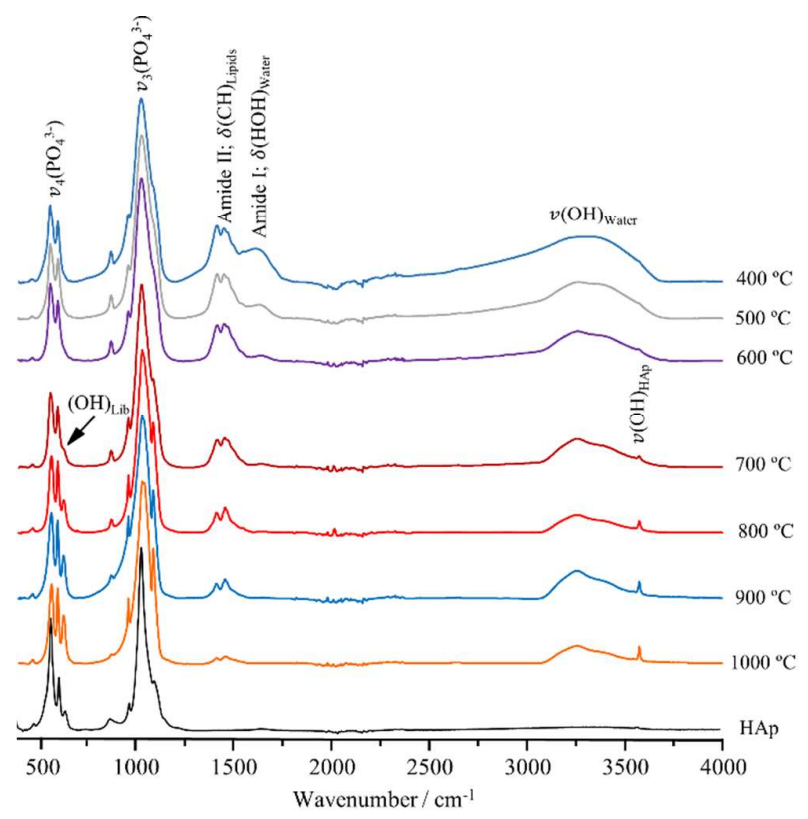

Figure 4. FTIR-ATR spectra of human femur from skeleton CC_NI_42 burned from 400 to $1000{ }^{\circ} \mathrm{C}$.

The FTIR OH signals $\left(\mathrm{OH}_{\text {lib }}\right.$ and $\left.v(\mathrm{OH})\right)$ were not visible in unburned samples nor in samples burned at temperatures up to $600{ }^{\circ} \mathrm{C}$. It was only for samples burned at $700{ }^{\circ} \mathrm{C}$ and above that these bands became visible. Snoeck et al. (16) reported OH/P ratios obtained through FTIR-ATR both for unburned and burned $\left(500\right.$ to $\left.900{ }^{\circ} \mathrm{C}\right)$ samples. Gonçalves et al. (75) chose to report data for bones burned at $700{ }^{\circ} \mathrm{C}$. In the current study, we decided to follow a different procedure.

At $700{ }^{\circ} \mathrm{C}$, the infrared $\mathrm{OH}$ librational signal often appeared as a shoulder of the $630 \mathrm{~cm}^{-1}$ band, while $v(\mathrm{OH})$ was detected as a very weak band (Figure 4). This is in agreement with previous reported studies $(37,41,61)$. In turn, Etok et al. (74) and Wang et al. (40) made the same observation at slightly lower burning temperatures (600 and $650{ }^{\circ} \mathrm{C}$, respectively). In this work, shoulders were observed for 69 out of 87 samples burned at $700{ }^{\circ} \mathrm{C}$, clear $\mathrm{OH}_{\mathrm{lib}}$ bands being present only in the remaining 18 spectra. Therefore, although burning conditions were the same for all bone specimens, some variation was found. Regrettably, we are unable to pinpoint the cause of such variation. 
Therefore, in order to correctly obtain the intensity of the $\mathrm{OH}_{\mathrm{lib}}$ and $v(\mathrm{OH})$ signals and calculate the $\mathrm{OH} / \mathrm{P}$ relationships according to Equations 1,2 and 3, spectral deconvolution should be implemented for samples burned at $700{ }^{\circ} \mathrm{C}$. In order to keep consistency in the analysis, we decided not to perform deconvolution for any sample because it would have been a too complex and timeconsuming procedure, taking into account our large dataset. For this reason, only the samples burned from $800{ }^{\circ} \mathrm{C}$ upwards were used for the statistical analysis since we feared that the less precise $\mathrm{OH} / \mathrm{P}$ values obtained for samples burned at $700{ }^{\circ} \mathrm{C}$, without deconvolution, could bias the results. Table 1 comprises the average $\mathrm{OH} / \mathrm{P}$ ratios presently obtained for the bone samples under analysis $(\mathrm{n}=263)$, as a function of temperature.

Table 1. $\mathrm{OH} / \mathrm{P}$ average and standard deviation values for the bone samples experimentally burned at 800,900 and $1000^{\circ} \mathrm{C}(\mathrm{n}=263)$.

\begin{tabular}{|c|c|c|c|}
\hline Temperature $\left({ }^{\circ} \mathrm{C}\right)$ & $\begin{array}{c}630 \mathrm{~cm}^{-1} / 603 \mathrm{~cm}^{-1} \\
\mathrm{OH}_{\text {lib }} / v\left(\mathrm{PO}_{4}\right)\end{array}$ & $\begin{array}{c}3572 \mathrm{~cm}^{-1} / 603 \mathrm{~cm}^{-1} \\
v(\mathrm{OH}) / v\left(\mathrm{PO}_{4}\right)\end{array}$ & $\begin{array}{c}3572 \mathrm{~cm}^{-1} / 1035 \mathrm{~cm}^{-1} \\
v(\mathrm{OH}) / v\left(\mathrm{PO}_{3}\right)\end{array}$ \\
\hline 800 & $0.5168 \pm 0.0536$ & $0.5502 \pm 0.0281$ & $0.5443 \pm 0.0110$ \\
\hline 900 & $0.1528 \pm 0.0838$ & $0.1527 \pm 0.0396$ & $0.1425 \pm 0.0173$ \\
\hline 1000 & $0.0588 \pm 0.0600$ & $0.0597 \pm 0.0345$ & $0.0555 \pm 0.0145$ \\
\hline
\end{tabular}

As expected, and similarly to what was observed in the INS spectra, the infrared $\mathrm{OH}$ bands became progressively sharper and more intense with increasing temperatures, from $c a$. 700 to 1000 ${ }^{\circ} \mathrm{C}$. In the case of the $\mathrm{OH}_{\text {lib }}$ signal, this general trend had been previously observed in other experiments $(37,41,61,76)$, except for the one carried out by Reidsma et al. (77) who were unable to detect any bands assigned to $\mathrm{OH}$ groups in their bovine bone samples. This was apparently not due to the specific taxonomic origin of the samples, since Snoeck et al. (16) also used bovine samples in their experiment and were nonetheless able to observe the $\mathrm{OH}$ infrared signals. Therefore, the interesting absence of $\mathrm{OH}$ in the experiment of Reidsma et al. (77) remains unexplained.

Statistical $\mathrm{OH} / \mathrm{P}$ differences between bone types regarding the $800-1000{ }^{\circ} \mathrm{C}$ maximum temperature thresholds are given in Table S-4 (for long, short and irregular bones). Results were quite variable according to each of the indexes obtained through Equations 1, 2, and 3. In the case of 
the $630 \mathrm{~cm}^{-1} / 603 \mathrm{~cm}^{-1}$ ratio, no significant differences among long, short, and irregular bones were detected for any of the maximum temperatures. Regarding $3572 \mathrm{~cm}^{-1} / 603 \mathrm{~cm}^{-1}$ and $3572 \mathrm{~cm}^{-1} / 1035$ $\mathrm{cm}^{-1}$, significant discrepancies were found only at $800{ }^{\circ} \mathrm{C}$ and $900{ }^{\circ} \mathrm{C}$, no significant differences having been observed at $1000{ }^{\circ} \mathrm{C}$.

However, this descriptive statistics (Table S-4) appears to be quite similar among bone types, even in those cases for which significant differences were obtained (never larger than 0.02 units). Besides, for the type of applications foreseen for the $\mathrm{OH} / \mathrm{P}$ index, regarding the assessment of how intensively burned are the bones, we assumed that the small absolute differences among bone types would not have a great impact on the subsequent inferences. Consequently, we decided to pool all bone types into one larger set of samples, thus strengthening our results.

The correlation tests among the presently obtained $\mathrm{OH} / \mathrm{P}$ indices provided significant results in all cases (Table S-5), thus suggesting that all the analysed bone samples exhibited the same behaviour in terms of heat-increment evolution, irrespectively of the type of bone. The assessment of pairwise multicollinearity among the three indices, by implementing linear regression analyses to predict maximum burning temperature, indicated that the two ratios based on the $3572 \mathrm{~cm}^{-1}$ signal provided the same information (variance inflation factor $(\mathrm{VIF})=9.184$ ). In contrast, it became clear that the input of the $630 \mathrm{~cm}^{-1} / 603 \mathrm{~cm}^{-1}$ index was substantially different from the inputs of the 3572 $\mathrm{cm}^{-1} / 603 \mathrm{~cm}^{-1}(\mathrm{VIF}=1.127)$ and of the $3572 \mathrm{~cm}^{-1} / 1035 \mathrm{~cm}^{-1}(\mathrm{VIF}=1.051)$. This suggests that the use of two different $\mathrm{OH} / \mathrm{P}$ indices is valuable for future regression models attempting to estimate the maximum temperature (as the one developed by Ellingham et al. (37)).

Given our results, the use of indices based on the $v(\mathrm{OH})$ band at $3572 \mathrm{~cm}^{-1}$ has one important advantage over the $\mathrm{OH}_{\text {lib }}$ signal at $630 \mathrm{~cm}^{-1}$, such as the absence of interference and/or superimposition with contiguous signals $\left(\right.$ e.g. $\left.v_{4}\left(\mathrm{PO}_{4}\right)\right)$. At $700{ }^{\circ} \mathrm{C}$ the $\mathrm{OH}_{\mathrm{lib}}$ band appears as a shoulder of the $360 \mathrm{~cm}^{-1}$ feature in the majority of the analysed samples thus preventing the precise calculation of its intensity. 
Regarding the $603 \mathrm{~cm}^{-1}$ and $1035 \mathrm{~cm}^{-1}$ phosphate bands, both are affected by contaminants, as reported by Piga et al. $(13,41,58,78)$, the latter being particularly influenced by the presence of fluorapatite (at $1090 \mathrm{~cm}^{-1}$ ) and several other phosphate vibrational modes (such as $v_{1}\left(\mathrm{HPO}_{4}{ }^{2-}\right)$, at $1005 \mathrm{~cm}^{-1}$ and $v_{1}\left(\mathrm{PO}_{4}{ }^{3-}\right)$, at $\left.960 \mathrm{~cm}^{-1}\right)$. This is the cause for the broadened signal at $1035 \mathrm{~cm}^{-1}$. Moreover, this band experiences a substantial redshift upon heating as opposed to the one at $603 \mathrm{~cm}^{-}$ ${ }^{1}$ that remains relatively stable. Also, this feature at $1035 \mathrm{~cm}^{-1}$ was used for spectra normalisation thus meaning that any calculation using it as denominator merely corresponds to the intensity of the numerator rather than to a true $\mathrm{OH} / \mathrm{P}$ ratio. For these reasons, the $603 \mathrm{~cm}^{-1}$ signal is more appropriate for the calculation of the indices.

Archaeological and fossilized remains usually contain several contaminants consequent of diagenetic processes such as calcite $\left(\mathrm{CaCO}_{3}\right)$, celestite $\left(\mathrm{SrSO}_{4}\right)$, gypsum $\left(\mathrm{CaSO}_{4} \cdot 2 \mathrm{H}_{2} \mathrm{O}\right)$, quartz $\left(\mathrm{SiO}_{2}\right)$, goethite $(\mathrm{FeO}(\mathrm{OH}))$, kaolinite $\left(\mathrm{Al}_{2} \mathrm{Si}_{2} \mathrm{O}_{5}(\mathrm{OH})_{4}\right)$, among others $(13,78-80)$. Their infrared bands will therefore add to the vibrational profile of bioapatite and may confuse the analysis and identification of the $\mathrm{OH}_{\mathrm{lib}}$ and $v(\mathrm{OH})$ features. The presence of these mineral phases must be evaluated through X-ray diffraction. Also, in the presence of such minerals, special care must be taken in the calculation based on infrared data due to band overlap.

The archaeological burned bones and teeth, and the fossil materials provided distinct spectra. Both presented the expected sharpened phosphate peaks typical of high crystallinity index values. However, the $\mathrm{OH}_{\text {lib }}$ and $v(\mathrm{OH})$ bands were detected only for the 25 archaeological samples and never for the 25 fossil samples. This could suggest that, although the fossil materials may mimic the crystallinity index values typical of burned skeletal remains, they may be differentiated through the presence of the $\mathrm{OH}$ bands. However, although infrequently, $\mathrm{OH}$ signals have indeed been reported for fossil bones $(69,70)$, so this is not always a reliable indicator of burned remains as opposed to fossils (the spectra of some selected samples are given in Figure 5). High crystallinity index values in either recent or archaeological burned skeletal materials should necessarily correspond to the 
detection of infrared $\mathrm{OH}$ signals, while their absence should be indicative of a more ancient material whose high crystallinity index resulted exclusively from the fossilization process.

Conversely, it seems that the $\mathrm{OH}$ signals may contribute for the identification of genuine archaeological skeletal remains subjected to burning. The fact that infrared $\mathrm{OH}$ peaks are only occasionally visible in fossils, however, is not yet well understood. A possible explanation could be the known mineralization of the bone that takes place during the fossilization process. This process can occur either by: i) replacement of the original hard bone constituents by silica, calcite, pyrite or hematite; or ii) perimineralization, when minerals dissolved in ground water are deposited in the microscopic pores and cavities of the matrix $(81,82)$. The result of this second process is a fossil that mainly contains the original hard bone constituents. The spectral data presently measured for fossilized samples appears to validate this latter hypothesis (perimineralization), as most of the hydroxyapatite signals could be identified, with the exception of those characteristic of the $\mathrm{OH}$ group, which may be explained by the substitution of these bioapatite's hydroxyls by anions such as $\mathrm{F}^{-}, \mathrm{Cl}^{-}$or $\mathrm{HCO}_{3}^{-}$. In fact, it is well known that fluoride ion incorporation in bone enhances in vitro mineralization, increases apatite's structural stability and induces a higher crystallinity (as currently observed). Furthermore, $\mathrm{Ca}^{2+}$ and $\mathrm{Mg}^{2+}$ (usually abundant in water and soils) are absorbed by the bone matrix and may bind to its $\mathrm{OH}$ released groups thus causing significant shifts of their characteristic vibrational bands, which can hinder their distinct observation.

\section{CONCLUSIONS}

The application of neutron spectroscopy techniques for the study of burned human remains is an innovative approach that allowed the observation of the characteristic $\mathrm{OH}$ vibrational signals of HAP at specific temperatures. This is extremely helpful for the analysis and interpretation of the data acquired through widely used methods, such as FTIR-ATR. In turn, the infrared OH bands of burned human bone samples appear to be of the utmost usefulness for the estimation of the maximum 
temperature at which skeletal remains were burned. In addition, they seem to help discriminating between genuine burned skeletal remains and fossilized remains (which generally display no $\mathrm{OH}$ signals despite their high crystallinity index). Such discriminant ability thus confers much more confidence on the analysis of archaeological remains, since this information is a pre-requisite for such analysis. In order to extract reliable bioarchaeological information, burned remains must be examined taking into consideration the possible impact of heat-induced changes. This can only be achieved once burned bones are clearly identified.
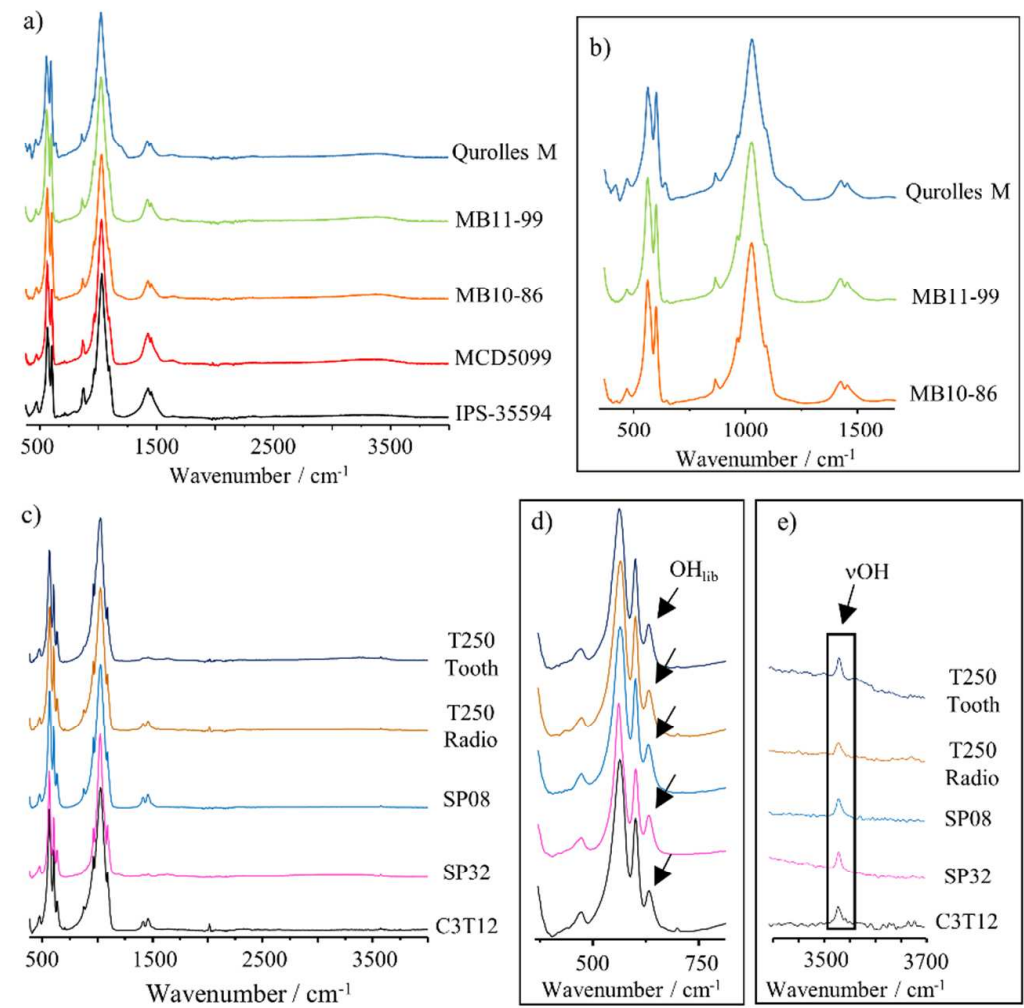

Figure 5. a) FTIR-ATR spectra of five fossil samples (Qurolles M, MB11-99, MB10-86, MCD5099 and IPS35594 ) in the $380-4000 \mathrm{~cm}^{-1}$ range; b) FTIR-ATR spectra of the Qurolles M, MB11-99 and MB10-86 fossil samples in the $380-1750 \mathrm{~cm}^{-1}$ range; c) FTIR-ATR spectra of five archaeological burned samples (T250Tooth, T250-Radio, SP08, SP32 and C3T12) in the $380-4000 \mathrm{~cm}^{-1}$ range; d) FTIR-ATR spectra of five archaeological burned samples (T250-Tooth, T250-Radio, SP08, SP32 and C3T12) in the $380-800 \mathrm{~cm}^{-1}$ range, highlighting the OH libration band $(\downarrow)$; e) FTIR-ATR spectra of five archaeological burned samples (T250-Tooth, T250-Radio, SP08, SP32 and C3T12) in the $3400-3700 \mathrm{~cm}^{-1}$ range, highlighting the $\mathrm{OH}$ stretch signal $(\downarrow)$. These are representative spectra of all the samples analysed in this work. 
The present study allowed us to identify the $630 \mathrm{~cm}^{-1} / 603 \mathrm{~cm}^{-1}$ index as providing accurate information, that is different from the one yielded by the $3572 \mathrm{~cm}^{-1} / 603 \mathrm{~cm}^{-1}$ and $3572 \mathrm{~cm}^{-1} / 1035$ $\mathrm{cm}^{-1}$ ratios. As a result, it appears that the use of the former combined with one of the other two can be beneficial to improve statistical models able to estimate maximum temperature, such as the ones from Thompson et al. (61) and Ellingham et al. (37). In addition, it was verified that the application of the $3572 \mathrm{~cm}^{-1} / 603 \mathrm{~cm}^{-1}$ index may be more advantageous relative to $3572 \mathrm{~cm}^{-1} / 1035 \mathrm{~cm}^{-1}$ index, namely because the $603 \mathrm{~cm}^{-1}$ signal is more stable than the one at $1035 \mathrm{~cm}^{-1}$. Nonetheless, this advantage of the $3572 \mathrm{~cm}^{-1} / 603 \mathrm{~cm}^{-1}$ index must be confirmed through additional research with specific applications such as temperature estimation.

\section{ASSOCIATED CONTENT}

\section{Supporting Information}

The Supporting Information is available free of charge on the ACS Publications website at DOI:

Includes lists of samples used in the present study and Tables with statistical analysis results as noted in text.

\section{AUTHOR INFORMATION \\ Corresponding Author \\ *E-mail: labc@ci.uc.pt}

\section{ORCID}

A. P. Mamede: 0000-0002-0647-4771

A. R. Vassalo: 0000-0002-3208-2309

G. Piga: 0000-0001-5133-5925

E. Cunha: 0000-0003-2998-371X

S. F. Parker: 0000-0002-3228-2570

M. P. M. Marques: 0000-0002-8391-0055

L. A. E. Batista de Carvalho: 0000-0002-8059-8537

D. Gonçalves: 0000-0002-0607-5631

\section{Notes}

The authors declare no competing financial interest. 


\section{ACKNOWLEDGEMENTS}

The authors acknowledge the financial support from the Portuguese Foundation for Science and Technology - SFRH/BPD/84268/2012; UID/MULTI/00070/2013; PEst-OE/SADG/UI0283/2013; PTDC/IVC-ANT/1201/2014; POCI-01-0145-FEDER-016766.

We thank Prof. Antonio Brunetti [Centro Interuniversitario di Ricerca sulle Tecnologie per i Beni Culturali (CIRTEBEC), University of Sassari, Italy] for allocating the laboratory facilities. We also acknowledge: Àngel Galobart (Institut Català de Paleontologia, Spain), Prof. Assumpció Malgosa (Universitat Autònoma de Barcelona, Spain), Museum of Terrassa (Spain) and Dr. Michele Guirguis (University of Sassari, Italy) for supplying fossils and archaeological materials employed in this study. The STFC Rutherford Appleton Laboratory is thanked for access to neutron beam facilities.

\section{REFERENCES}

(1) Arroyo, A. B. M.; Ruiz, M. D. L.; Bernabeu, G. V.; Román, R. S.; Morales, M. R. G.; Straus, L. G. Archaeological Implications of Human-Derived Manganese Coatings: A Study of Blackened Bones in El Mirón Cave. J. Archaeol. Sci. 2008, 35, 801-813.

(2) Beasley, M. M.; Bartelink, E. J.; Taylor, L.; Miller, R. M. Comparison of Transmission FTIR, ATR, and DRIFT Spectra: Implications for Assessment of Bone Bioapatite Diagenesis. J. Archaeol. Sci. 2014, 46, 1622.

(3) Squires, K. E.; Thompson, T. J. U.; Islam, M.; Chamberlain, A. The Application of Histomorphometry and Fourier Transform Infrared Spectroscopy to the Analysis of Early Anglo-Saxon Burned Bone. $J$. Archaeol. Sci. 2011, 38, 2399-2409.

(4) Stiner, M.; Kuhn, S.; Weiner, S.; Bar-Yosef, O. Differential Burning, Recrystallization, and Fragmentation of Archaeological Bone. J. Archaeol. Sci. 1995, 22, 223-237.

(5) Stiner, M. C.; Kuhn, S. L.; Surovell, T. A.; Goldberg, P.; Meignen, L.; Weiner, S.; Bar-Yosef, O. Bone Preservation in Hayonim Cave (Israel): A Macroscopic and Mineralogical Study. J. Archaeol. Sci. 2001, 28 (6), 643-659.

(6) Surovell, T. A.; Stiner, M. C. Standardizing Infra-Red Measures of Bone Mineral Crystallinity: An Experimental Approach. J. Archaeol. Sci. 2001, 28 (6), 633-642.

(7) Thompson, T. J. U.; Gauthier, M.; Islam, M. The Application of a New Method of Fourier Transform Infrared Spectroscopy to the Analysis of Burned Bone. J. Archaeol. Sci. 2009, 36 (3), 910-914.

(8) Weiner, S.; Bar-Yosef, O. States of Preservation of Bones from Prehistoric Sites in the Near East: A 
Survey. J. Archaeol. Sci. 1990, 17 (2), 187-196.

(9) Dal Sasso, G.; Lebon, M.; Angelini, I.; Maritan, L.; Usai, D.; Artioli, G. Bone Diagenesis Variability among Multiple Burial Phases at Al Khiday (Sudan) Investigated by ATR-FTIR Spectroscopy. Palaeogeogr. Palaeoclimatol. Palaeoecol. 2016, 463, 168-179.

(10) Ellingham, S. T. D.; Thompson, T. J. U.; Islam, M.; Taylor, G. Estimating Temperature Exposure of Burnt Bone - A Methodological Review. Sci. Justice 2015, 55 (3), 181-188.

(11) Hollund, H. I.; Ariese, F.; Fernandes, R.; Jans, M. M. E.; Kars, H. Testing an Alternative HighThroughput Tool for Investigating Bone Diagenesis: Ftir in Attenuated Total Reflection (Atr) Mode. Archaeometry 2013, 55 (3), 507-532.

(12) Lebon, M.; Reiche, I.; Bahain, J. J.; Chadefaux, C.; Moigne, A. M.; Fröhlich, F.; Sémah, F.; Schwarcz, H. P.; Falguères, C. New Parameters for the Characterization of Diagenetic Alterations and Heat-Induced Changes of Fossil Bone Mineral Using Fourier Transform Infrared Spectrometry. J. Archaeol. Sci. 2010, 37 (9), 2265-2276.

(13) Piga, G.; Santos-Cubedo, A.; Brunetti, A.; Piccinini, M.; Malgosa, A.; Napolitano, E.; Enzo, S. A Multi-Technique Approach by XRD, XRF, FT-IR to Characterize the Diagenesis of Dinosaur Bones from Spain. Palaeogeogr. Palaeoclimatol. Palaeoecol. 2011, 310 (1-2), 92-107.

(14) Schiegl, S.; Goldberg, P.; Pfretzschner, H.-U.; Conard, N. J. Paleolithic Burnt Bone Horizons from the Swabian Jura: Distinguishing Betweenin Situ Fireplaces and Dumping Areas. Geoarchaeology 2003, 18 (5), $541-565$.

(15) Shahack-Gross, R.; Bar-Yosef, O.; Weiner, S. Black-Coloured Bones in Hayonim Cave, Israel: Differentiating Between Burning and Oxide Staining. J. Archaeol. Sci. 1997, 24 (5), 439-446.

(16) Snoeck, C.; Lee-Thorp, J. A.; Schulting, R. J. From Bone to Ash: Compositional and Structural Changes in Burned Modern and Archaeological Bone. Palaeogeogr. Palaeoclimatol. Palaeoecol. 2014, 416, 55-68.

(17) Herrmann, B. On Histological Investigations of Cremated Human Remains. J. Hum. Evol. 1977, 6 (2), 101-103.

(18) Shipman, P.; Foster, G.; Schoeninger, M. Burnt Bones and Teeth: An Experimental Study of Color, Morphology, Crystal Structure and Shrinkage. J. Archaeol. Sci. 1984, 11 (4), 307-325.

(19) Nicholson, R. A. A Morphological Investigation of Burnt Animal Bone and an Evaluation of Its Utility in Archaeology. J. Archaeol. Sci. 1993, 20, 411-428.

(20) Holden, J. L.; Phakey, P. P.; Clement, J. G. Scanning Electron Microscope Observations of HeatTreated Human Bone. Forensic Sci. Int. 1995, 74 (1-2), 29-45.

(21) Binford, L. R. An Analysis of Cremations from Three Michigan Sites. Wisconsin Archaeol. 1963, 44, 98-110.

(22) Herrmann, B. Experimentelle Und Theoretische Beiträge Zur Leichenbrand Unter Schung. Homo 1976, 27, 114-118.

(23) van Vark, G. N.; Amesz-Voorhoeve, W.; Cuijpers, A. Sex-Diagnosis of Human Cremated Skeletal 
Material by Means of Mathematical-Statistical and Data-Analytical Methods. Homo 1996, 47, 305-338.

(24) Wahl, J. K. Erfahrungen Zur Metrishen Geschlechtsdiagnose Bei Leichenbränden. Homo 1996, 47, $339-359$.

(25) Thompson, T. J. U. Recent Advances in the Study of Burned Bone and Their Implications for Forensic Anthropology. Forensic Sci. Int. 2004, 146, S203-S205.

(26) Thompson, T. J. U. Heat-Induced Dimensional Changes in Bone and Their Consequences for Forensic Anthropology. J. Forensic Sci. 2005, 50, 185-193.

(27) Ubelaker, D. H. The Forensic Evaluation of Burned Skeletal Remains: A Synthesis. Forensic Sci. Int. 2009, $183(1-3), 1-5$.

(28) Symes, S. A.; Rainwater, C. W.; Chapman, E. N.; Gipson, D. R.; Piper, A. L. Patterned Thermal Destruction in a Forensic Setting. In The analyses of burned human remains; Schmidt, C. W., Symes, S. A., Eds.; Academic Press: London, UK, 2015; pp 17-60.

(29) Gonçalves, D.; Cunha, E.; Thompson, T. J. U. Estimation of the Pre-Burning Condition of Human Remains in Forensic Contexts. Int. J. Legal Med. 2014, 129 (5), 1137-1143.

(30) Vassalo, A. R.; Mamede, A. P.; Ferreira, M. T.; Cunha, E.; Gonçalves, D. The G-Force Awakens: The Influence of Gravity in Bone Heat-Induced Warping and Its Implications for the Estimation of the PreBurning Condition of Human Remains. Aust. J. Forensic Sci. 2018. DOI: 10.1080/00450618.2017.1340521

(31) Bellard, F. El Análisis Antropológico de Las Cremaciones. Complutum extra 1996, 6 (2), 55-64.

(32) Théry-Parisot, I. Fuel Management (Bone and Wood) During the Lower Aurignacian in the Pataud Rock Shelter (Lower Palaeolithic, Les Eyzies de Tayac, Dordogne, France). Contribution of Experimentation. J. Archaeol. Sci. 2002, 29 (12), 1415-1421.

(33) Solari, A.; Olivera, D.; Gordillo, I.; Bosch, P.; Fetter, G.; Lara, V. H.; Novelo, O. Cooked Bones? Method and Practice for Identifying Bones Treated at Low Temperature. Int. J. Osteoarchaeol. 2015, 25 (4), 426-440.

(34) Hiller, J. C.; Thompson, T. J. U.; Evison, M. P.; Chamberlain, A. T.; Wess, T. J. Bone Mineral Change during Experimental Heating: An X-Ray Scattering Investigation. Biomaterials 2003, 24 (28), 5091-5097.

(35) Piga, G.; Malgosa, A.; Thompson, T. J. U.; Enzo, S. A New Calibration of the XRD Technique for the Study of Archaeological Burned Human Remains. J. Archaeol. Sci. 2008, 35 (8), 2171-2178.

(36) Piga, G.; Thompson, T. J. U.; Malgosa, A.; Enzo, S. The Potential of X-Ray Diffraction in the Analysis of Burned Remains from Forensic Contexts. J. Forensic Sci. 2009, 54 (3), 534-539.

(37) Ellingham, S. T. D.; Thompson, T. J. U.; Islam, M. The Effect of Soft Tissue on Temperature Estimation from Burnt Bone Using Fourier Transform Infrared Spectroscopy. J. Forensic Sci. 2016, 61, 153159.

(38) Boskey, J. A.; Gokhale, A. L.; Robey, P. G. The Biochemistry of Bone. In Osteoporosis; Marcus, R., Feldman, D., Kelsey, J., Eds.; Academic Press: Stanford, California, 2001; pp 107-188.

(39) Lee, C. L.; Einhorn, T. A. The Bone Organ System - Form and Function. In Osteoporosis; Marcus, R., Feldman, D., Kelsey, J., Eds.; Academic Press: Stanford, California, 2001; pp 3-20. 
(40) Wang, X. Y.; Zuo, Y.; Huang, D.; Hou, X. D.; Li, Y. B. Comparative Study on Inorganic Composition and Crystallographic Properties of Cortical and Cancellous Bone. Biomed. Environ. Sci. 2010, 23 (6), 473480 .

(41) Piga, G.; Baró, M. D.; Escobal, I. G.; Gonçalves, D.; Makhoul, C.; Amarante, A.; Malgosa, A.; Enzo, S.; Garroni, S. A Structural Approach in the Study of Bones: Fossil and Burnt Bones at Nanosize Scale. Appl. Phys. A 2016, 122 (12), 1031.

(42) LeGeros, R. Z.; Trautz, O. R.; Klein, E.; LeGeros, J. P. Two Types of Carbonate Substitution in the Apatite Structure. Experientia 1969, 25 (1), 5-7.

(43) Rey, C.; Collins, B.; Goehl, T.; Dickson, I. R.; Glimcher, M. J. The Carbonate Environment in Bone Mineral: A Resolution-Enhanced Fourier Transform Infrared Spectroscopy Study. Calcif. Tissue Int. 1989, 45 (3), 157-164.

(44) Mamede, A. P.; Gonçalves, D.; Marques, M. P. M.; Batista de Carvalho, L. A. E. Burned Bones Tell Their Own Stories: A Review of Methodological Approaches to Assess Heat-Induced Diagenesis. Appl. Spectrosc. Rev. 2018, 53(8), 603-635.

(45) Trueman, C. N. G.; Behrensmeyer, A. K.; Tuross, N.; Weiner, S. Mineralogical and Compositional Changes in Bones Exposed on Soil Surfaces in Amboseli National Park, Kenya: Diagenetic Mechanisms and the Role of Sediment Pore Fluids. J. Archaeol. Sci. 2004, 31 (8), 721-739.

(46) Stathopoulou, E. T.; Psycharis, V.; Chryssikos, G. D.; Gionis, V.; Theodorou, G. Bone Diagenesis: New Data from Infrared Spectroscopy and X-Ray Diffraction. Palaeogeogr. Palaeoclimatol. Palaeoecol. 2008, $266(3-4), 168-174$.

(47) Holcomb, D. W.; Young, R. A. Thermal Decomposition of Human Tooth Enamel. Calcif. Tissue Int. 1980, 31 (1), 189-201.

(48) Person, A.; Bocherens, H.; Mariotti, A.; Renard, M. Diagenetic Evolution and Experimental Heating of Bone Phosphate. Palaeogeogr. Palaeoclimatol. Palaeoecol. 1996, 126 (1-2), 135-149.

(49) Gonçalves, D.; Thompson, T. J. U.; Cunha, E. Osteometric Sex Determination of Burned Human Skeletal Remains. J. Forensic Leg. Med. 2013, 20 (7), 906-911.

(50) Loong, C.-K.; Rey, C.; Kuhn, L. T.; Combes, C.; Wu, Y.; Chen, S.-H.; Glimcher, M. J. Evidence of Hydroxyl-Ion Deficiency in Bone Apatites: An Inelastic Neutron-Scattering Study. Bone 2000, 26, 599-602.

(51) Pasteris, J. D.; Wopenka, B.; Freeman, J. J.; Rogers, K.; Valsami-Jones, E.; Van Der Houwen, J. A. M.; Silva, M. J. Lack of OH in Nanocrystalline Apatite as a Function of Degree of Atomic Order: Implications for Bone and Biomaterials. Biomaterials 2004, 25 (2), 229-238.

(52) Taylor, M. G.; Parker, S. F.; Simkiss, K.; Mitchell, P. C. H. Bone Mineral: Evidence for Hydroxy Groups by Inelastic Neutron Scattering. Phys. Chem. Chem. Phys. 2001, 3 (8), 1514-1517.

(53) Taylor, M. G.; Parker, S. F.; Mitchell, P. C. H. A Study by High Energy Transfer Inelastic Neutron Scattering Spectroscopy of the Mineral Fraction of Ox Femur Bone. J. Mol. Struct. 2003, 651-653, 123-126.

(54) Cho, G.; Wu, Y.; Ackerman, J. L. Detection of Hydroxyl Ions in Bone Mineral by Solid-State NMR Spectroscopy. Science (80-. ). 2003, 300 (5622), 1123-1127. 
(55) Marques, M. P. M.; Gonçalves, D.; Amarante, A. I. C.; Makhoul, C. I.; Parker, S. F.; Batista de Carvalho, L. A. E. Osteometrics in Burned Human Skeletal Remains by Neutron and Optical Vibrational Spectroscopy. RSC Adv. 2016, 6 (73), 68638-68641.

(56) Termine, J. D.; Posner, A. S. Amorphous/Crystalline Interrelationships in Bone Mineral. Calcif. Tissue Res. 1967, 1 (1), 8-23.

(57) Thompson, T. J. U.; Islam, M.; Piduru, K.; Marcel, A. An Investigation into the Internal and External Variables Acting on Crystallinity Index Using Fourier Transform Infrared Spectroscopy on Unaltered and Burned Bone. Palaeogeogr. Palaeoclimatol. Palaeoecol. 2011, 299 (1-2), 168-174.

(58) Piga, G.; Gonçalves, D.; Thompson, T. J. U.; Brunetti, A.; Malgosa, A.; Enzo, S. Understanding the Crystallinity Indices Behavior of Burned Bones and Teeth by ATR-IR and XRD in the Presence of Bioapatite Mixed with Other Phosphate and Carbonate Phases. Int. J. Spectrosc. 2016, 2016, 1-9.

(59) Cascant, M. M.; Rubio, S.; Gallello, G.; Pastor, A.; Garrigues, S.; Guardia, M. de la. Burned Bones Forensic Investigations Employing near Infrared Spectroscopy. Vib. Spectrosc. 2017, 90, 21-30.

(60) Sponheimer, M.; Lee-Thorp, J. a. Alteration of Enamel Carbonate Environments during Fossilization. J. Archaeol. Sci. 1999, 26 (2), 143-150.

(61) Thompson, T. J. U.; Islam, M.; Bonniere, M. A New Statistical Approach for Determining the Crystallinity of Heat-Altered Bone Mineral from FTIR Spectra. J. Archaeol. Sci. 2013, 40 (1), 416-422.

(62) Vassalo, A. R.; Cunha, E.; de Carvalho, L. A. E. B.; Gonçalves, D. Rather Yield than Break: Assessing the Influence of Human Bone Collagen Content on Heat-Induced Warping through Vibrational Spectroscopy. Int. J. Legal Med. 2016, 130 (6), 1647-1656.

(63) Morris, M. D.; Mandair, G. S. Raman Assessment of Bone Quality. Clin. Orthop. Relat. Res. 2011, 469 (8), 2160-2169.

(64) France, C. A. M.; Thomas, D. B.; Doney, C. R.; Madden, O. FT-Raman Spectroscopy as a Method for Screening Collagen Diagenesis in Bone. J. Archaeol. Sci. 2014, 42 (1), 346-355.

(65) Gamsjaeger, S.; Hofstetter, B.; Fratzl-Zelman, N.; Roschger, P.; Roschger, A.; Fratzl, P.; Brozek, W.; Masic, A.; Misof, B. M.; Glorieux, F. H.; et al. Pediatric Reference Raman Data for Material Characteristics of Iliac Trabecular Bone. Bone 2014, 69, 89-97.

(66) Roschger, A.; Gamsjaeger, S.; Hofstetter, B.; Masic, A.; Blouin, S.; Messmer, P.; Berzlanovich, A.; Paschalis, E. P.; Roschger, P.; Klaushofer, K.; et al. Relationship between the V $\square$ PO $\square /$ Amide III Ratio Assessed by Raman Spectroscopy and the Calcium Content Measured by Quantitative Backscattered Electron Microscopy in Healthy Human Osteonal Bone. J. Biomed. Opt. 2014, 19 (6), 065002.

(67) Bachman, C. H.; Ellis, E. H. Fluorescence of Bone. Nature 1965, 206 (4991), 1328-1331.

(68) Ferreira, M. T.; Vicente, R.; Navega, D.; Gonçalves, D.; Curate, F.; Cunha, E. A New Forensic Collection Housed at the University of Coimbra, Portugal: The 21st Century Identified Skeletal Collection. Forensic Sci. Int. 2014, 245, 202.e1-202.e5.

(69) Roche, D.; Ségalen, L.; Balan, E.; Delattre, S. Preservation Assessment of Miocene-Pliocene Tooth Enamel from Tugen Hills (Kenyan Rift Valley) through FTIR, Chemical and Stable-Isotope Analyses. $J$. 
Archaeol. Sci. 2010, 37 (7), 1690-1699.

(70) Leduc, T. Diagenesis of the Fossil Bones of Iguanodon Bernissartensis from the Iguanodon Sinkhole. In Bernissart Dinossaurs and Early Cretacious terrestrial ecosystems; Godefroit, P., Ed.; Indiana University Press: Bloomington, IN, 2012; pp 113-136.

(71) ISIS Neutron and Muon Source of the Rutherford Appleton Laboratory https://www.isis.stfc.ac.uk/Pages/home.aspx\# (accessed May 22, 2018).

(72) Parker, S. F.; Lennon, D.; Albers, P. W. Vibrational Spectroscopy with Neutrons: A Review of New Directions. Appl. Spectrosc. 2011, 65 (12), 1325-1341.

(73) Arnold, O.; Bilheux, J. C.; Borreguero, J. M.; Buts, A.; Campbell, S. I.; Chapon, L.; Doucet, M.; Draper, N.; Ferraz Leal, R.; Gigg, M. A.; et al. Mantid-Data Analysis and Visualization Package for Neutron Scattering and $\mu$ SR Experiments. Nucl. Instruments Methods Phys. Res. Sect. A Accel. Spectrometers, Detect. Assoc. Equip. 2014, 764, 156-166.

(74) Etok, S. E.; Valsami-Jones, E.; Wess, T. J.; Hiller, J. C.; Maxwell, C. A.; Rogers, K. D.; Manning, D. A. C.; White, M. L.; Lopez-Capel, E.; Collins, M. J.; et al. Structural and Chemical Changes of Thermally Treated Bone Apatite. J. Mater. Sci. 2007, 42 (23), 9807-9816.

(75) Gonçalves, D.; Vassalo, A. R.; Mamede, A. P.; Makhoul, C.; Piga, G.; Cunha, E.; Marques, M. P. M.; Batista de Carvalho, L. A. E. Crystal Clear: Vibrational Spectroscopy Reveals Intrabone, Intraskeleton, and Interskeleton Variation in Human Bones. Am. J. Phys. Anthropol. 2018, 166 (2), 296-312.

(76) Munro, L. E.; Longstaffe, F. J.; White, C. D. Burning and Boiling of Modern Deer Bone: Effects on Crystallinity and Oxygen Isotope Composition of Bioapatite Phosphate. Palaeogeogr. Palaeoclimatol. Palaeoecol. 2007, 249 (1-2), 90-102.

(77) Reidsma, F. H.; van Hoesel, A.; van Os, B. J. H.; Megens, L.; Braadbaart, F. Charred Bone: Physical and Chemical Changes during Laboratory Simulated Heating under Reducing Conditions and Its Relevance for the Study of Fire Use in Archaeology. J. Archaeol. Sci. Reports 2016, 10, 282-292.

(78) Piga, G.; Marmi, J.; Galobart, À.; Brunetti, A.; Lasio, B.; Malfatti, L.; Enzo, S. New Data on the Presence of Celestite into Fossil Bones from the Uppermost Cretaceous Molí Del Baró-1 Site (Spain) and an Alternative Hypothesis on Its Origin. Spectrochim. Acta Part B 2016, 119, 41-49.

(79) Piga, G.; Guirguis, M.; Bartoloni, P.; Malgosa, A.; Enzo, S. A Funerary Rite Study of the PhoenicianPunic Necropolis of Mount Sirai (Sardinia, Italy). Int. J. Osteoarchaeol. 2010, 20 (2), 144-157.

(80) Piga, G.; Brunetti, A.; Lasio, B.; Malfatti, L.; Galobart, À.; Dalla Vecchia, F. M.; Enzo, S. New Insights about the Presence of Celestite into Fossil Bones from Molí Del Baró 1 Site (Isona i Conca Dellá, Lleida, Spain). Appl. Phys. A 2015, 118 (2), 487-496.

(81) Thomas, D. B.; Fordyce, R. E.; Frew, R. D.; Gordon, K. C. A Rapid, Non-Destructive Method of Detecting Diagenetic Alteration in Fossil Bone Using Raman Spectroscopy. J. Raman Spectrosc. 2007, 38 (12), 1533-1537.

(82) Henderson, P.; Marlow, C. A.; Molleson, T. I.; Williams, C. T. Patterns of Chemical Change during Bone Fossilization. Nature 1983, 306 (5941), 358-360. 


\title{
Potential of Bioapatite Hydroxyls for Research on Archaeological Burned Bone
}

\author{
Adriana P. Mamede ${ }^{1}$, Ana R. Vassalo ${ }^{1,2,3}$, Giampaolo Piga ${ }^{3}$, Eugénia Cunha ${ }^{3,4}$, Stewart F. Parker ${ }^{5}$, \\ M. Paula M. Marques ${ }^{1,4}$, Luís A. E. Batista de Carvalho ${ }^{1 *}$, David Gonçalves ${ }^{2,3,6}$ \\ ${ }^{1}$ Unidade de I\&D “Química-Física Molecular”, Department of Chemistry, University of Coimbra, Portugal \\ ${ }^{2}$ Research Centre for Anthropology and Health (CIAS), Department of Life Sciences, University of Coimbra, Portugal \\ ${ }^{3}$ Laboratory of Forensic Anthropology, Centre for Functional Ecology, Department of Life Sciences, University of Coimbra, \\ ${ }^{4}$ Department of Life Sciences, University of Coimbra, Portugal \\ ${ }^{5}$ ISIS Facility, STFC Rutherford Appleton Laboratory, Chilton, Didcot, OX 11 0QX, United Kingdom \\ ${ }^{6}$ Archaeosciences Laboratory, Directorate General for Cultural Heritage (LARC/CIBIO/InBIO), Lisbon, Portugal
} Portugal

\section{Supporting Information}

Table of Contents:

Table S-1 - Distribution of human bone samples according to maximum temperature of burning $\left({ }^{\circ} \mathrm{C}\right)$

Table S-2 - List of archaeological samples used in this study.

Table S-3 - List of fossil samples used in this study.

Table S-4 - Descriptive statistics of the three $\mathrm{OH} / \mathrm{P}$ indices investigated in this study and statistical differences among bone types (through Kruskall-Wallis tests) according to maximum temperature of burning $\left(800,900\right.$ and $\left.1000{ }^{\circ} \mathrm{C}\right)$.

Table S-5 - Results of the Spearman rho rank correlation tests among $\mathrm{OH} / \mathrm{P}$ indices investigated in this study for bones burned at 800, 900 and $1000{ }^{\circ} \mathrm{C}$. 
Table S-1 - Distribution of human bone samples according to maximum temperature of burning $\left({ }^{\circ} \mathrm{C}\right)$.

\begin{tabular}{|c|c|c|c|c|c|c|c|c|}
\hline \multirow[t]{2}{*}{ Bone } & \multicolumn{2}{|c|}{ CC_NI_31 } & \multicolumn{2}{|c|}{ CC_NI_32 } & \multicolumn{2}{|c|}{ CC_NI_33 } & \multicolumn{2}{|c|}{ CC_NI_34 } \\
\hline & Left & Right & Left & Right & Left & Right & Left & Right \\
\hline Clavicle & 600 & 400 & 700 & 500 & 1000 & 800 & - & 900 \\
\hline Humerus & 700 & - & 600 & 400 & 500 & 900 & 1000 & 700 \\
\hline Radius & 1000 & 800 & 900 & 700 & 600 & 400 & 400 & 600 \\
\hline Ulna & 900 & 700 & 800 & 1000 & 700 & 400 & 500 & 800 \\
\hline MC1 & 700 & 400 & 600 & 500 & 500 & 800 & - & - \\
\hline MC2 & - & - & 900 & 700 & 1000 & 800 & 1000 & - \\
\hline MC3 & 900 & 600 & 600 & 400 & 700 & 900 & - & - \\
\hline MC4 & 500 & 1000 & 800 & 500 & 400 & 600 & - & - \\
\hline MC5 & - & - & 1000 & 400 & 700 & 500 & - & - \\
\hline Femur & 900 & 400 & 400 & 900 & 1000 & 600 & 500 & a) \\
\hline Tibia & 500 & 1000 & 1000 & 800 & 700 & 900 & 800 & 400 \\
\hline Fibula & 600 & 400 & 800 & 500 & 400 & 900 & 900 & 600 \\
\hline MT1 & 900 & 700 & 1000 & 600 & 800 & 500 & 400 & 800 \\
\hline MT2 & 1000 & 800 & 900 & 700 & 600 & 1000 & 700 & 900 \\
\hline MT3 & 600 & 400 & 800 & 500 & - & 800 & 500 & 1000 \\
\hline MT4 & 700 & 500 & 600 & 400 & 900 & 600 & 1000 & 800 \\
\hline MT5 & 1000 & - & 900 & 700 & 700 & 400 & 400 & 600 \\
\hline Calcaneus & 400 & 900 & 700 & - & 800 & 500 & 500 & 700 \\
\hline Talus & 700 & - & 800 & 400 & 400 & 700 & 900 & 600 \\
\hline Cuboid & 900 & 600 & 1000 & 500 & 600 & 800 & 700 & 400 \\
\hline Navicular & 700 & 800 & 900 & 600 & 500 & 900 & 800 & 1000 \\
\hline Medial cuneiform & - & 500 & 600 & 900 & 500 & 1000 & 1000 & 800 \\
\hline Middle cuneiform & - & - & 400 & 700 & - & 600 & 700 & 900 \\
\hline Lateral cuneiform & 1000 & - & 800 & 500 & 400 & - & 600 & 400 \\
\hline
\end{tabular}

${ }^{\text {a) }}$ Only unburned samples were collected. 
Table S-2 - List of archaeological samples used in this study.

\begin{tabular}{|c|c|c|c|}
\hline Sample & Site of provenance & Chronology & Element \\
\hline 2.118 & Necropolis of Can Missert (Terrassa, Spain) & 1.000-900 B.C. (Bronze Age) & skull \\
\hline 2.118.3 & Necropolis of Can Missert (Terrassa, Spain) & 1.000-900 B.C. (Bronze Age) & diaphysis \\
\hline 2.121 & Necropolis of Can Missert (Terrassa, Spain) & 1.000-900 B.C. (Bronze Age) & skull \\
\hline 2.121 & Necropolis of Can Missert (Terrassa, Spain) & 1.000-900 B.C. (Bronze Age) & diaphysis \\
\hline 2.106 & Necropolis of Can Missert (Terrassa, Spain) & 1.000-900 B.C. (Bronze Age) & diaphysis \\
\hline SP32 & Necropolis of Sebes (Flix Ribere d'Ebre, Tarragona, Spain) & 900-800 B.C. (Iron Age) & tooth \\
\hline SP08 & Necropolis of Sebes (Flix Ribere d’Ebre, Tarragona, Spain) & 800-500 B.C. (Iron Age) & skull \\
\hline SP27 & Necropolis of Sebes (Flix Ribere d'Ebre, Tarragona, Spain) & 500-400 B.C. (Iron Age) & skull \\
\hline $\mathbf{T 2 5 0}$ & Necropolis of Monte Sirai (Carbonia, Italy) & VI century B.C. (Iron Age) & skull \\
\hline $\mathbf{T 2 5 0}$ & Necropolis of Monte Sirai (Carbonia, Italy) & VI century B.C. (Iron Age) & mandible \\
\hline $\mathbf{T 2 5 0}$ & Necropolis of Monte Sirai (Carbonia, Italy) & VI century B.C. (Iron Age) & radius \\
\hline T250 & Necropolis of Monte Sirai (Carbonia, Italy) & VI century B.C. (Iron Age) & tooth \\
\hline T252 & Necropolis of Monte Sirai (Carbonia, Italy) & VI century B.C. (Iron Age) & rib \\
\hline T252 & Necropolis of Monte Sirai (Carbonia, Italy) & VI century B.C. (Iron Age) & ulna \\
\hline T252 & Necropolis of Monte Sirai (Carbonia, Italy) & VI century B.C. (Iron Age) & tooth \\
\hline T252 & Necropolis of Monte Sirai (Carbonia, Italy) & VI century B.C. (Iron Age) & mandible \\
\hline T252 & Necropolis of Monte Sirai (Carbonia, Italy) & VI century B.C. (Iron Age) & femur \\
\hline T252 & Necropolis of Monte Sirai (Carbonia, Italy) & VI century B.C. (Iron Age) & radius \\
\hline T252 & Necropolis of Monte Sirai (Carbonia, Italy) & VI century B.C. (Iron Age) & tibia \\
\hline T252 & Necropolis of Monte Sirai (Carbonia, Italy) & VI century B.C. (Iron Age) & vertebra \\
\hline C3T12 & Necropolis of Aguilar de Montuenga (Soria, Spain) & IV-III century B.C (Iron Age) & diaphysis \\
\hline C3T14-2 & Necropolis of Aguilar de Montuenga (Soria, Spain) & IV-III century B.C (Iron Age) & diaphysis \\
\hline C4T5 & Necropolis of Aguilar de Montuenga (Soria, Spain) & IV-III century B.C (Iron Age) & diaphysis \\
\hline C5T2 & Necropolis of Aguilar de Montuenga (Soria, Spain) & IV-III century B.C (Iron Age) & diaphysis \\
\hline C5T11 & Necropolis of Aguilar de Montuenga (Soria, Spain) & IV-III century B.C (Iron Age) & diaphysis \\
\hline
\end{tabular}


Table S-3 - List of fossil samples used in this study.

\begin{tabular}{|c|c|c|c|}
\hline Sample & Site of provenance & Chronology & Specimen \\
\hline IPS-35594 & Menorca & Middle Triassic (Anisian) (245 Ma) & Seimuromorpha \\
\hline Patiras & Todolella (Castellón) & Lower Cretaceous (Aptian) (125-112 Ma) & Dinosauria (undet.) \\
\hline Qurolles-M & Portell (Castellón) & Lower Cretaceous (Aptian) (125-112 Ma) & Dinosauria (Ornithopoda) \\
\hline MB10-41 & Isona (Lleida) & Upper Cretaceous (75-65 Ma) & Crocodyliform tooth (ziphodont) \\
\hline MB10-86 & Isona (Lleida) & Upper Cretaceous (75-65 Ma) & Theropod tooth \\
\hline MB10-114 & Isona (Lleida) & Upper Cretaceous (75-65 Ma) & Theropod tooth \\
\hline MB10-144 & Isona (Lleida) & Upper Cretaceous (75-65 Ma) & Theropod tooth \\
\hline MB10-195 & Isona (Lleida) & Upper Cretaceous (75-65 Ma) & Crocodyle tooth \\
\hline MB11-99 & Isona (Lleida) & Upper Cretaceous (75-65 Ma) & Crocodyle tooth \\
\hline MB11-115 & Isona (Lleida) & Upper Cretaceous (75-65 Ma) & Crocodyle tooth \\
\hline MB11-122 & Isona (Lleida) & Upper Cretaceous (75-65 Ma) & Crocodyle tooth \\
\hline MCD-6684 & Isona (Lleida) & Upper Cretaceous (75-65 Ma) & Dinosauria (caudal vertebra) \\
\hline MCD-5099 & Isona (Lleida) & Upper Cretaceous (75-65 Ma) & Dinosauria (ischion) \\
\hline MCD-5589 & Isona (Lleida) & Upper Cretaceous (75-65 Ma) & Dinosauria (sacral vertebra) \\
\hline MCD-6645 & Isona (Lleida) & Upper Cretaceous (75-65 Ma) & Dinosauria (rib fragment) \\
\hline MCD-6647 & Isona (Lleida) & Upper Cretaceous (75-65 Ma) & Dinosauria (rib) \\
\hline MB 6-5-2010_1 & Isona (Lleida) & Upper Cretaceous (75-65 Ma) & Dinosauria (undet.) \\
\hline MB 6-5-2010_2 & Isona (Lleida) & Upper Cretaceous (75-65 Ma) & Dinosauria (undet.) \\
\hline MB 6-5-2010_3 & Isona (Lleida) & Upper Cretaceous (75-65 Ma) & Dinosauria (undet.) \\
\hline MB 6-5-2010_4 & Isona (Lleida) & Upper Cretaceous (75-65 Ma) & Dinosauria (undet.) \\
\hline NE12F & Vilamitjana (Lleida) & Upper Cretaceous (Maastrichtian)(70-65 Ma) & Dinosauria (ischion fragment) \\
\hline Bfum017 & $\begin{array}{c}\text { Fumanya } \\
\text { (Fígols-Vallcebre) }\end{array}$ & Upper Cretaceous (Maastrichtian)(70-65 Ma) & Crocodyliform (undet.) \\
\hline TB-3 & Orcau (Lleida) & Upper Cretaceous (75-65 Ma) & Testudines (plate) \\
\hline Orcau-1 & Orcau (Lleida) & Upper Cretaceous (75-65 Ma) & Dinosauria (Hadrosauria) \\
\hline Espinau & Espinau (Lleida) & Upper Cretaceous (75-65 Ma) & Dinosauria (Hadrosauria) \\
\hline IPS-37438 & $\begin{array}{c}\text { Roc de Santa } \\
\text { (Conca de Dalt) (Lleida) }\end{array}$ & Eocene (Priabonian) (33.9-37.2 Ma) & Reptilian (undet.) \\
\hline
\end{tabular}

Key: undet. $=$ undetermined anatomical element 
Table S-4 - Descriptive statistics of the three $\mathrm{OH} / \mathrm{P}$ indices investigated and statistical differences among bone types (through Kruskall-Wallis tests) according to maximum temperature of burning (800, 900 and $1000{ }^{\circ} \mathrm{C}$ ).

\begin{tabular}{|c|c|c|c|c|c|c|c|c|c|c|c|c|c|c|c|c|}
\hline \multirow{2}{*}{$\begin{array}{l}\text { Bone } \\
\text { Type }\end{array}$} & \multirow[b]{2}{*}{${ }^{\circ} \mathrm{C}$} & \multicolumn{5}{|c|}{$630 \mathrm{~cm}^{-1} / 603 \mathrm{~cm}^{-1}\left(\mathrm{OH}_{\text {lib }} / v\left(\mathrm{PO}_{4}\right)\right)$} & \multicolumn{5}{|c|}{$3572 \mathrm{~cm}^{-1} / 603 \mathrm{~cm}^{-1}\left(v(\mathrm{OH}) / v\left(\mathrm{PO}_{4}\right)\right)$} & \multicolumn{5}{|c|}{$3572 \mathrm{~cm}^{-1} / 1035 \mathrm{~cm}^{-1}\left(v(\mathrm{OH}) / v\left(\mathrm{PO}_{3}\right)\right)$} \\
\hline & & $\mathbf{n}$ & Mean & SD & Min & Max & $\mathbf{n}$ & Mean & SD & Min & Max & n & Mean & SD & Min & Max \\
\hline \multirow{3}{*}{$\begin{array}{l}\text { Long } \\
\text { Bones }\end{array}$} & 800 & 41 & 0.52 & 0.05 & 0.37 & 0.6 & 41 & $0.14^{* * *}$ & 0.03 & 0.09 & 0.2 & 41 & $0.06^{* * *}$ & 0.01 & 0.03 & 0.08 \\
\hline & 900 & 56 & 0.55 & 0.04 & 0.45 & 0.65 & 56 & $0.14^{*}$ & 0.04 & 0.09 & 0.24 & 56 & $0.06^{* * *}$ & 0.02 & 0.03 & 0.10 \\
\hline & 1000 & 42 & $0.56 *$ & 0.05 & 0.42 & 0.65 & 42 & 0.14 & 0.04 & 0.10 & 0.29 & 42 & 0.06 & 0.01 & 0.04 & 0.11 \\
\hline \multirow{3}{*}{$\begin{array}{l}\text { Short } \\
\text { Bones }\end{array}$} & 800 & 28 & 0.52 & 0.06 & 0.38 & 0.6 & 28 & $0.17 * * *$ & 0.03 & 0.11 & 0.23 & 28 & $0.06^{* * *}$ & 0.01 & 0.04 & 0.09 \\
\hline & 900 & 27 & 0.56 & 0.14 & 0.25 & 0.94 & 27 & $0.16^{*}$ & 0.04 & 0.09 & 0.23 & 27 & $0.06^{* * *}$ & 0.02 & 0.03 & 0.09 \\
\hline & 1000 & 31 & $0.53^{*}$ & 0.07 & 0.32 & 0.64 & 31 & 0.14 & 0.04 & 0.08 & 0.21 & 31 & 0.05 & 0.02 & 0.03 & 0.09 \\
\hline \multirow{3}{*}{$\begin{array}{c}\text { Irregular } \\
\text { Bones }\end{array}$} & 800 & 14 & 0.51 & 0.05 & 0.41 & 0.58 & 14 & $0.16^{* * *}$ & 0.02 & 0.13 & 0.19 & 14 & $0.06^{* * *}$ & 0.01 & 0.05 & 0.08 \\
\hline & 900 & 14 & 0.54 & 0.04 & 0.49 & 0.61 & 14 & $0.18^{*}$ & 0.04 & 0.11 & 0.23 & 14 & $0.07 * * *$ & 0.02 & 0.04 & 0.10 \\
\hline & 1000 & 10 & $0.53^{*}$ & 0.03 & 0.47 & 0.57 & 10 & 0.15 & 0.03 & 0.12 & 0.22 & 10 & 0.06 & 0.01 & 0.05 & 0.09 \\
\hline
\end{tabular}


Table S-5 - Results of the Spearman rho rank correlation tests among $\mathrm{OH} / \mathrm{P}$ indices investigated in this study for bones burned at 800, 900 and $1000{ }^{\circ} \mathrm{C}$.

\begin{tabular}{|c|c|c|c|c|}
\hline Index & $\begin{array}{l}\text { Maximum } \\
\text { Temperature }\end{array}$ & $630 \mathrm{~cm}^{-1} / 603 \mathrm{~cm}^{-1}$ & $3572 \mathrm{~cm}^{-1} / 603 \mathrm{~cm}^{-1}$ & $3572 \mathrm{~cm}^{-1} / 1035 \mathrm{~cm}^{-1}$ \\
\hline \multirow{3}{*}{$\begin{array}{c}630 \mathrm{~cm}^{-1} / 603 \mathrm{~cm}^{-1} \\
\left(\mathrm{OH}_{\mathrm{lib}} / v\left(\mathrm{PO}_{4}\right)\right)\end{array}$} & $800{ }^{\circ} \mathrm{C}$ & - & $0.373^{* *}$ & $0.507^{* *}$ \\
\hline & $900^{\circ} \mathrm{C}$ & - & $0.371^{* * *}$ & $0.250^{*}$ \\
\hline & $1000{ }^{\circ} \mathrm{C}$ & - & $0.406^{* * *}$ & $0.426 * * *$ \\
\hline \multirow{3}{*}{$\begin{array}{c}3572 \mathrm{~cm}^{-1} / 603 \mathrm{~cm}^{-1} \\
\left(v(\mathrm{OH}) / v\left(\mathrm{PO}_{4}\right)\right)\end{array}$} & $800^{\circ} \mathrm{C}$ & $0.373^{* *}$ & - & $0.950 * * *$ \\
\hline & $900^{\circ} \mathrm{C}$ & $0.371^{* * *}$ & - & $0.923 * * *$ \\
\hline & $1000{ }^{\circ} \mathrm{C}$ & $0.406^{* * *}$ & - & $0.989 * * *$ \\
\hline \multirow{3}{*}{$\begin{array}{c}3572 \mathrm{~cm}^{-1} / 1035 \mathrm{~cm}^{-1} \\
\left.\left(v(\mathrm{OH}) / v \mathrm{PO}_{3}\right)\right)\end{array}$} & $800{ }^{\circ} \mathrm{C}$ & $0.507^{* *}$ & $0.950 * * *$ & - \\
\hline & $900^{\circ} \mathrm{C}$ & $0.250^{*}$ & $0.923 * * *$ & - \\
\hline & $1000{ }^{\circ} \mathrm{C}$ & $0.426 * * *$ & $0.989 * * *$ & - \\
\hline
\end{tabular}

